https://doi.org/10.52240/1857-2367.2020.2(21).31

\title{
THE USE OF THE FOREST MANAGEMENT DATABASE IN THE PROCESS OF PRIMARY SELECTION OF STANDS WITHIN FOREST GENETIC RESOURCES
}

\author{
Ludmila TALMACI', Ala MARDARI I, , Ion TALMACII, \\ I "Al. Ciubotaru” National Botanical Garden (Institute), \\ Chisinau, Republic of Moldova \\ ${ }^{2}$ Forest Research and Management Institute, \\ Chisinau, Republic of Moldova
}

\begin{abstract}
The forest management database is used for the primary selection of the candidate stands for inclusion in forest genetic resources (FGR). The management and primary processing of the forest management database was performed with the support of standard functions of commonly used software (Microsoft Excel). In 2020, the primary identification area of FGR was 75.7 thousand ha of land covered with forests in the central area of the Republic of Moldova. As a result of the data processing, 12.7 thousand ha, or $16.8 \%$ of the study area, of candidate stands were selected for inclusion in the FGR.
\end{abstract}

Key words: forest genetic resources, forest management database, stand selection criteria.

The identification and description of new FGR are basic elements of the research and innovation project 20.80009,7007.01 "Assessment of Wild Vegetation in the Republic of Moldova for the Conservation and Sustainable Use of Plant Diversity and Plant Genetic Resources in the Context of Adaptation to Climate Change." FGR is the most valuable set of stands with high adaptive potential, which supports the maintenance and conservation of the native gene pool, contributes to obtaining propagation material for the reconstruction of degraded and unsuitable stands, as well as for the expansion of forests on new lands [1].

Within the mentioned project, the process of identification and selection of the new sectors suitable for inclusion in the FGR is staggered in several stages and activities. The initial stage of the selection process includes detailed in-office analysis of forest management data [2] to identify candidate stands for inclusion in FGR. At the current stage, the activity is focused on the 4 forest entities (Forest Enterprises Calarasi, Hancesti-Silva, Nisporeni-Silva, Silva-Centru Ungheni) with the total area of the forest fund of 81.0 thousand ha [2], including 75.7 thousand ha of land covered with forests (93.3\%), which in fact represents the primary identification area of FGR.

The choice of forest management data as the main source of primary data for the identification of FGR was made, because it contains most of the information about the current state of the stands, expressed by 39 indicators mentioned in the plot descriptions (area of the management unit, soil type, site type, relief, stand composition, current character of the forest type, density, origin, way of regeneration etc.). Another important advantage of forest management data is the possibility of primary processing by using relatively simple data-processing functions (sorting, filter, pivot table etc.) of commonly used computer applications (Microsoft Excel etc.).

At the initial stage, it was necessary to correlate the indicators in the forest management data with the requirements that had to be met by the stands to be included in the FGR category. Thus, the main indicators for the identification of candidate stands for the FGR were 
established and classified according to importance: the current character of the forest type (fundamental natural stands), the predominant base species (native species: oak, sessile oak, beech, white poplar, black poplar), production class (1-4), age (>40 years), density $(\geq 0.7)$, origin (natural regeneration). Other indicators are secondary, informative and will be considered in the next stages of FGR selection.

As a result of data processing, a total of 12.7 thousand ha of candidate stands were selected to be included in the FGR, or $16.8 \%$ of the studied area. Higher percentages of stands suitable for FGR were found in FE Calarasi (37.6\%) and FE Nisporeni-Silva (13.1\%). This fact confirms the value of the forests within the two forest entities for the conservation of forest genetic resources. The data obtained will be used as primary material for the subsequent stage of FGR selection, which is a much more complex one and includes field examination and validation. Besides, the forest management data will be used at the final stage of institutional approval of the FGR and the registration in the National Catalogue of Forest Genetic Resources of the Republic of Moldova.

\section{BIBLIOGRAPHY}

1. Enescu V., 1993. Identificarea, eşantionarea, prospectarea, descrierea şi clasificarea resurselor genetice forestiere (RGF). Îndrumări metodologice, Manuscris ICAS București.

2. ICAS Chișinău, 2011-2020. Amenajamentele silvice pentru entităţile ÎS Călăraşi, ÎS HânceştiSilva, ÎS Nisporeni-Silva, ÎS Silva-Centru Ungheni. 